\title{
Pengaruh Bauran Komunikasi Pemasaran Terpadu Terhadap Niat Berkunjung Wisatawan Pada Objek Wisata Air Terjun Way Lalaan Kota Agung Kabupaten Tanggamus Provinsi Lampung
}

\author{
Haskhory Ginaldho ${ }^{1}$, Aida Sari ${ }^{2}$, Afri Aripin ${ }^{3}$ \\ 1-3Universitas Lampung, Lampung, email: haskhiory.vrima@gmail.com \& \\ aida.sari@feb.unila.ac.id afriarifin@gmail.com
}

\begin{abstract}
Abstrak, Pariwisata merupakan salah satu sektor yang berpeluang dalam meningkatkan anggaran pendapatan daerah. Teluk Kiluan terletak di Kelumbayan, Kabupaten Tanggamus, Provinsi Lampung yang merupakan salah satu objek wisata unggulan yang dimiliki Provinsi Lampung dan terkenal dengan keindahan pesona laut terutama daya tarik ikan lumba-lumbanya. Penelitian ini bertujuan untuk mengetahui bagaimana Bauran Komunikasi Pemasaran Terpadu dalam menarik Niat Berkunjung wisatawan di Objek Wisata Air Terjun Way Lalaan, Kota Agung, Kabupaten Tanggamus, Provinsi Lampung. Metode pengambilan sampel menggunakan metode non probability sampling dengan teknik purposive sampling. Populasi dalam penelitian adalah wisatawan yang belum pernah mengunjungi Air Terjun Way Lalaan dan wisatawan domestik dengan jumlah sampel 100 responden. Metode analisis statistik yang digunakan adalah regresi linier berganda, pengujian signifikan simultan uji $(F)$, pengujian signifikan parsial (uji t), dan analisis determinasi (R2). Hasil penelitian ini menunjukkan bahwa: Periklanan (X1), Promosi Penjualan (X2), Penjualan Personal (X3), Pemasaran Langsung (X4), Hubungan Masyarakat (X5) dan e-WOM (X6) berpengaruh positif secara signifikan dengan sumbangan sebesar $82,4 \%$ terhadap Niat Berkunjung. Hasil penelitian dengan menggunakan analisis kuantitatif membuktikan bahwa variabel dengan nilai beta terbesar adalah Periklanan (X1) yang memiliki nilai beta sebesar 0,440 sedangkan variabel Promosi Penjualan (X2) memberikan pengaruh terkecil dengan nilai beta sebesar 0,109
\end{abstract}

Kata kunci: Bauran Komunikasi; Pemasaran Terpadu; Niat Berkunjung

Abstract. Tourism is one of the vital sector that has an opportunity to increase the regional revenue budget. Way Lalaan Waterfall is located in Kota Agung, Tanggamus Regency, Lampung Province, which is one of the leading tourist attractions in Lampung Province and is famous for its clear water and preserved natural beauty. Way Lalaan Waterfall fluctuates in terms of the number of visitors who come. This study aims to determine how the Integrated Marketing Communication Mix in attracting tourist visiting intentions at Way Lalaan Waterfall Tourism Object, Kota Agung, Tanggamus Regency, Lampung Province. The sampling method used non- probability sampling 
method with purposive sampling technique. The populations in this study were tourists who had never visited Way Lalaan Waterfall and domestic tourists with a sample size of 100 respondents. The statistical analysis method used is multiple linear regression, simultaneous significant test $(F)$, partial significance testing ( $t$ test), and determination analysis (R2). The results of this study show that: Advertising (X1), Sales Promotion (X2), Personal Selling (X3), Direct Marketing (X4), Public Relations (X5) and e-WOM (X6) have a significant positive effect with a contribution of $82,4 \%$ of Intention to Visit. The results of quantitative analysis prove that the variable with the largest beta value is Advertising (X1) which has a beta value of 0.440 while the Sales Promotion variable (X2) has the smallest effect with a beta value of 0.109 .

Keywords : Integrated Marketing: Communication Mix: Visiting Tourists.

\section{A. PENDAHULUAN}

Pariwisata merupakan sektor yang ikut berperan penting dalam usaha peningkatan pendapatan. Indonesia merupakan negara yang memiliki keindahan alam dan keanekaragaman budaya, sehingga perlu adanya peningkatan sektor pariwisata. Hal ini dikarenakan pariwisata merupakan sektor yang dianggap menguntungkan dan sangat berpotensi untuk dikembangkan sebagai salah satu aset yang di gunakan untuk sumber peningkatan penghasilan bagi bangsa dan negara.

Berdasarkan data Badan Pusat Statistik (BPS) tercatat ada 16,11 juta wisatawan mancanegara (wisman) pada 2019. Jika dibandingkan pada tahun 2018 yang sebelumnya 15,81 juta wisman, jumlah ini naik 1,88 persen. Hal ini menggambarkan bagaimana besarnya potensi wisata yang dimiliki bangsa ini untuk dapat mendatangkan turis asing ke dalam negeri. Bauran Komunikasi Pemasaran Terpadu seperti (iklan, penjualan personal, pemasaran langsung, promosi penjualan, hubungan masyarakat dan e-WOM) diharapkan dapat memperkenalkan serta mengembangkan suatu pariwisata khususnya dalam meningkatkan niat berkunjung wisatawan.

Air Terjun Way Lalaan terletak di kaki Gunung Tanggamus dan merupakan air terjun bertingkat dengan jarak kurang lebih 200 m. Nama Air terjun ini berasal dalam bahasa Lampung dari kata "Way" yang artinya sungai dan Lalaan yang bermuara ke Teluk Semangka. Tumpahan air terjun ini memiliki ketinggian $\pm 11 \mathrm{~m}$. Air terjun yang di kenal sejak Tahun 1937 yaitu pada zaman pemerintahan Belanda yang ditandai telah membuat sebuah tangga yang terbuat dari semen menuju lembah air terjun. Lokasi Air terjun Way Lalaan ini mempunyai 2 air terjun. Warga sekitar memberi nama Air Terjun Way Lalaan 1 yang terletak di atas dan Air Terjun Way Lalaan 2 yang terletak di bawah.

Jumlah wisatawan selama 4 tahun rata-rata yang berkunjung sebanyak 9134 orang pertahun, artinya wisatawan yang datang perbulan rata-rata hanya 761 wisatawan yang berkunjung ke Air Terjun Way Lalaan di Kabupaten Tanggamus, Provinsi Lampung. Pertumbuhan wisatawan $8,3 \%$. Standar yang ditetapkan oleh Dinas Pariwisata Kabupaten Tanggamus yaitu sebesar $15 \%$ pertahun ini artinya masih jauh dibawah standar yang telah di tetapkan oleh Dinas Pariwisata Kabupaten Tanggamus. Pengunjung wisatawan yang berubah jumlahnya atau adanya fluktuasi karena keadaan alam seperti curah hujan yang tinggi dan kurangnya promosi di Objek wisata air terjun way lalaan, Kabupaten Tanggamus, Provinsi Lampung. (Rencana Strategis Dinas Pariwisata Tanggamus; 2018). Dapat dilihat Jurnal Pemasaran Kompetitif, Vol. 04, No. 2 / Februari 2021 
pada tabel 1 dibawah ini mengenai jumlah wisatawan yang berkunjung ke Air Terjun Way Lalaan.

Tabel 1. Jumlah Kunjungan Wisatawan ke Way Lalaan Tahun 2016-2019

\begin{tabular}{|c|c|c|c|}
\hline Nomor. & Tahun & $\begin{array}{c}\text { Jumlah Pengunjung } \\
\text { (orang) }\end{array}$ & $\begin{array}{c}\text { Perubahan } \\
(\%)\end{array}$ \\
\hline 1 & 2016 & 7803 & - \\
\hline 2 & 2017 & 7883 & 31.70 \\
\hline 3 & 2018 & 10382 & 0.83 \\
\hline 4 & 2019 & 10468 & - \\
\hline & $\begin{array}{c}\text { Rata- } \\
\text { Rata }\end{array}$ & 9134 & \\
\hline
\end{tabular}

Sumber: Dinas Pariwisata Kabupaten Tanggamus, 2019

Kegiatan komunikasi pemasaran guna mempromosikan keindahan Air Terjun Way Lalaan terus dilakukan oleh Dinas Paariwisata Tanggamus. Kegiatan komunikasi pemasaran yang dilakukan pengelola mengimplementasikan komunikasi pemasaran terpadu melalui banner, website dan juga memberikan diskon pada tiket masuk pengunjung.

Adapun komunikasi pemasaran terpadu yang telah dilakukan oleh Dinas Pariwisata Tanggamus adalah:

1.Iklan (Advertising)

Air Terjun Way Lalaan menggunakan media iklan melalui media cetak maupun elektronik seperti banner dan media sosial (Instagram dan Youtobe)

a.Banner

Way Lalaan melakukan Advertising dengan menggunakan Banner di beberapa lokasi di Kabupaten Tanggamus. Banner atau disebut Place Advertising (Iklan Tempat) adalah kategori luas yang mencakup banyak bentuk kreatif dan tak terduga untuk meraih perhatian konsumen. Alasannya adalah pemasar lebih baik menjangkau orang-orang ditempat ramai seperti tempat orang bekerja, bermain dan berbelanja.

b.Media Sosial (Instagram : @majestic.tanggamus dan Youtobe: Majestic Tanggamus)

Mengiklankan pariwisata melalui instagram cukup mudah hanya dengan memposting gambar Air Terjun Way Lalaan dan berbagi dengan yang lainnya, maka Way Lalaan akan tersebar melalui postingan gambar yang lain. @majestic.tanggamus adalah nama instagram yang dikelola oleh Dinas Pariwisata Tanggamus untuk mempromosikan semua objek destinasi yang ada di Kabupaten Tanggamus salah satunya Way Lalaan. Instagram ini sendiri sudah diikuti oleh 1.566 pengikut dengan postingan sebanyak 446 foto. Informasi dalam instagram tersebut terdapat informasi mengenai status akun yang dikelola oleh Dinas Pariwisata Tanggamus dan juga akun ini memberikan link bio yang akan diarahkan langsung ke Youtobe Channel Majestic Tanggamus yang juga mempromosikan keindahan alam di Kabupaten Begawi Jejama. Informasi pada Instagram @majestic.tanggamus dapat di percaya dengan didukung oleh gambar dan video pada instagram nya. 


\section{Promosi Penjualan (Sales Promotion)}

Strategi Sales Promotion yang digunakan oleh Dinas Pariwisata Kabupaten Tanggamus adalah dengan memberikan kupon berupa penukaran tiket untuk produk Teh Kotak kepada wisatawan di Air Terjun Way Lalaan. Tiket masuk pengunjung bisa ditukarkan dengan Minuman Teh Kotak sesuai dengan banyaknya jumlah tiket/kupon yang ditukarkan kepada Pemangku Wisata Arter Way Lalaan. Strategi ini harapannya kedepan bisa memberikan dampak positif bagi Pengelola maupun Dinas Pariwisata Tanggamus dalam mensukseskan kegiatan pemasaran kepada wisatawan khususnya menciptakan Niat Berkunjung ke Air Terju Way Lalaan.

3.Penjualan Personal (Personal Selling)

Penjualan langsung tatap muka atau personal selling merupakan kegiatan terpenting khususnya dalam komunikasi pemasaran dalam bidang pariwisata. Dinas pariwisata Tanggamus sering mengadakan pameran-pameran mengenai pariwisata, salah satunya adalah "Festival Teluk Semaka" yang merupakan pesta tahunan masyarakat

Tanggamus dalam mengeksplorasi Wisata dan Budaya setempat. Objek Way Lalaan selalu menjadi tuan rumah bagi acara tersebut. Tujuannya adalah selain mempromosikan budaya Tanggamus para pengelola juga dapat memperkenalkan Way Lalaan sebagai destinasi wisata unggulan. Harapannya kedepan dengan acara yang diselenggarakan di Way Lalaan tersebut dapat memberikan Branding yang kuat dikalangan wisatawan.

Terkahir Dinas Pariwisata Tanggamus mempromosikan dan memperkenalkan objek Way Lalaan dikancah nasional dengan ikut serta dalam acara "Gebyar Wisata dan Budaya Nusantara" di Jakarta Convention Center. Acara tahunan Kemenpar ini selalu masuk ke dalam agenda Dinas Pariwisata Tanggamus, karena acara tersebut merupakan peluang bagi Dispar untuk memasarkan potensi objek wisatanya secara personal (Personal Selling), mengingat acara tersebut juga banyak sekali dikunjungi oleh wisatawan domestik maupun mancanegara.

4.Pemasaran Langsung (Dircet Marketing)

Dinas Pariwisata Tanggamus bersama penggiat wisata objek Way Lalaan menerapkan konsep Catalog Marketing untuk kategori Direct Marketing (Kotler, Amstrong, Ang, Leong, Tan \& Tse) Catalog berupa Brosur cetak yang berisikan tentang objek wisata Way Lalaan mulai dari view gambar lokasi, informasi fasilitas, pelayanan Tourism Information Center hingga daftar harga tiket masuk objek wisata. Catalog juga menginformasikan askses dan jarak tempuh perjalanan menuju lokasi dengan titik awal ibukota Lampung dari Kota Bandar Lampung menuju Kabupaten Tanggamus tepatnya lokasi Way Lalaan yaitu Kota Agung Timur. Duta pariwisata atau biasa disebut "Muli Mekhanai" beperan penting dalam melakukan komunikasi produk catalog tersebut ketika berada disuatu event wisata. Mereka bertujuan untuk mensosialisasikan dan memperkenalkan kepada wisatawan produk wisata apa saja yang ada di Kabupaten Tanggamus khususnya Objek Air Terjun Way Lalaan melalui Brosur atau Catalog Marketing tersebut.

5.Hubungan Masyarakat (Human Relation)

Dalam mengimplementasikan komunikasi pemasaran terpadu, pengelola pariwisata juga harus melakukan hubungan masyarakat yang keuntungannya dapat memberikan citra yang baik kepada masyarakat. Festival Teluk Semaka yang menjadi kalender tahunan Dispar Tanggamus memberikan askes luas kepada masyarakat untuk ikut serta dalam mengelola dan mengembangkan objek Way Lalaan. Agenda seperti "Tour D'Semaka" telah mengundang banyak para penggiat wisata ikut kedalam acaranya. Vlogger, Blogger hingga 
Youtober asal Lampung mapun luar Lampung dengan konten wisata membantu destinasi ini agar lebih dikenal masyarakat luas.

Kelompok Sadar Wisata (Pokdarwis) juga berperan penting dalam melakukan kontribusi terhadap pengembangan pariwisata agar terciptanya Sapta Pesona suatu destinasi wisata setempat yang memiliki unsur keamanan, tertib, bersih, ramah, indah, sejuk dan kenangan. Air Terjun Way Lalaan juga memiliki hubungan kerjasama dengan masyarakat setempat dalam mengembangkan sektor wisata Way Lalaan, selain itu tujuan Pokdarwis ini agar Dinas Pariwisata Tanggamus dapat menjangkau wisatawan dengan masif dari bantuan masyarakat baik dari segi promosi, jual beli sektor UMKM seperti makanan khas Tanggamus "Otak- Otak" dan kegiatan kemasyarakatan dengan unsur budaya setempat.

6.e-WOM

Adapun untuk komunikasi eWOM yang mengulas Air Terjun Way Lalaan secara khusus dapat dilihat dari beberapa potongan gambar (screenshot) testimonial atau review mengenai Air Terjun Way Lalaan yang diambil dari beberapa sosial media seperti Facebook dan Instagram. Hasil dari review menjelaskan bahwa ada beberapa ulasan yang diberikan oleh wisatawan yang telah berkunjung mulai dari tanggapan mengenai daya tarik air terjun hingga saran-saran berupa evaluasi kedepan mengenai penambahan fasilitas.

Berdasarkan dari Tabel 1 mengenai data pengunjung dan persentase perubahan wisatawan ke air terjun way lalaan, Kabupaten Tanggamus Provinsi Lampung dari tahun 2016-2019 persentase pertumbuhan wisatawan sebesar 8,3\%. Persentase ini jauh dari target Dinas Pariwisata Kabupaten Tangamus yaitu sebesar $15 \%$. Hal ini disebabkan oleh beberapa permasalahan seperti, ketidakstabilan ekonomi masyarakat, penyampaian promosi yang tidak tepat sasaran dan ketidakefektifan penggunaan media promosi. Permasalahan dalam penelitian ini Apakah Bauran Komunikasi Pemasaran Terpadu berpengaruh signifikan terhadap Niat Berkunjung Wisatawan di Air Terjun Way Lalaan Kabupaten Tanggamus.

\section{KAJIAN LITERATUR}

Komunikasi pemasaran adalah sarana dimana perusahaan berusaha menginformasikan, membujuk, dan mengingatkan konsumen mengenai produk dan merek yang dijual. Menurut (Kotler dan Keller, 2012) Komunikasi pemasaran merupakan "suara" perusahaan dan mereknya, perusahaan dapat membuat dialog dan membangun hubungan dengan konsumen .

Komunikasi pemasaran yang terintegrasi merupakan suatu konsep yang sederhana. Konsep ini memastikan bahwa semua komunikasi dan pesan- pesan dihubungkan bersama-sama secara hati-hati. Pada tingkat yang paling mendasar, komunikasi pemasaran yang terintegrsi atau IMC berarti pengintegrasian semua alat-alat promosi yang ada sehingga alat-alat tersebut bekerja sama dengan selaras.

Adapun definisi dari keenam elemen dalam IMC dapat dijelaskan sebagai berikut. Kotler dan Keller (2012)

1.Periklanan (Advertising)

Periklanan dapat diartikan sebagai setiap bentuk presentasi non personal, promosi ide, barang atau jasa berbayar dengan sponsor tertentu, yang diidentifikasi melalui media cetak (surat kabar dan majalah), disiarkan melalui media radio dan televisi, media jaringan (telepon, kabel, satelit, nirkabel), elektronik media (rekaman suara, rekaman video, video 
disk, CD-ROM, halaman web), dan media display (papan reklame, tanda, poster). Kotler dan Keller, (2012). Iklan dapat membentuk citra merek dan mencapai penjualan yang cepat. Audiens dari iklan dapat menyebar secara luas baik dalam kota, luar kota, bahkan luar negeri. Tujuan iklan harus mengalir dari keputusan sebelumnya tentang pasar sasaran, positioning merek, dan program pemasaran. Tujuan iklan adalah tugas komunikasi khusus dan tingkat pencapaian yang harus dicapai dengan pemirsa tertentu dalam jangka waktu tertentu

\section{Promosi Penjualan (Sales Promotion)}

Promosi penjualan adalah berbagai intensif jangka pendek untuk mendorong uji coba atau pembelian suatu produk atau layanan termasuk promosi konsumen (seperti kupon dan premi), promosi dagang (seperti tunjangan iklan dan tampilan), dan tenaga penjualan dan bisnis promosi (kontes untuk perwakilan penjualan). Kotler dan Keller (2012).

3.Hubungan Masyarakat (Human Relation)

Hubungan masyarakat merupakan berbagai program yang diarahkan secara internal kepada karyawan perusahaan atau eksternal kepada konsumen, perusahaan lain, pemerintah, dan media untuk mempromosikan atau melindungi citra perusahaan atau komunikasi produk individualnya.(Kotler dan Keller, 2012)4.

4. Penjualan Personal (Personal Selling)

Penjualan personal adalah interaksi tatap muka dengan satu atau lebih calon pembeli untuk tujuan membuat presentasi, menjawab pertanyaan, dan pengadaan pesanan. Kotler dan Keller (2012)

5.Pemasaran langsung (Direct Marketing)

Pemasaran langsung bisa diartikan sebagai hubungan langsung dengan konsumen yang telah ditentukan secara cermat untuk mendapatkan respons segera dan membangun hubungan pelanggan yang kuat. Dalam konteks ini proses komunikasi dapat dilakukan dengan surat, telepon, TV interaktif, email dan lainnya yang memungkinkan terjadinya interaksi langsung dengan konsumen. Kotler dan Keller (2012)

6.e-WOM

Menurut Fang Chen-Ling dan Lie Ting, dalam Journal of American Academy of Business (2006), e-marketing adalah Proses memasarkan produk dan layanan kepada pelanggan dengan menggunakan media web. Promosi, Iklan, Transaksi dan pembayaran dapat dilakukan melalui halaman web. Pengguna internet marketing dapat dengan mudah mengakses informasi dimana saja dengan komputer yang terhubung ke internet

Niat Berkunjung

Niat berkunjung berasal dari teori Niat Beli. Niat atau Intensi adalah keputusan untuk bertindak dengan cara tertentu, atau dorongan untuk melakukan suatu tindakan, baik secara sadar atau tidak. Sudarsono (1993) berpendapat bahwa intensi adalah niat, tujuan; keinginan untuk melakukan sesuatu, mempunyai tujuan. Fishbein dan Ajzen (1975) mendefinisikan intensi sebagai probabilitas subjektif yang dimiliki seseorang untuk melakukan perilaku tertentu. Intensi akan tetap menjadi kecenderungan berperilaku sampai pada saat yang tepat ada usaha yang dilakukan untuk mengubah intensi tersebut menjadi sebuah perilaku. Ajzen (2005).

Dari penjelasan diatas maka dibuat model penelitian. Dapat dilihat model penelitian pada gambar dibawah ini: 


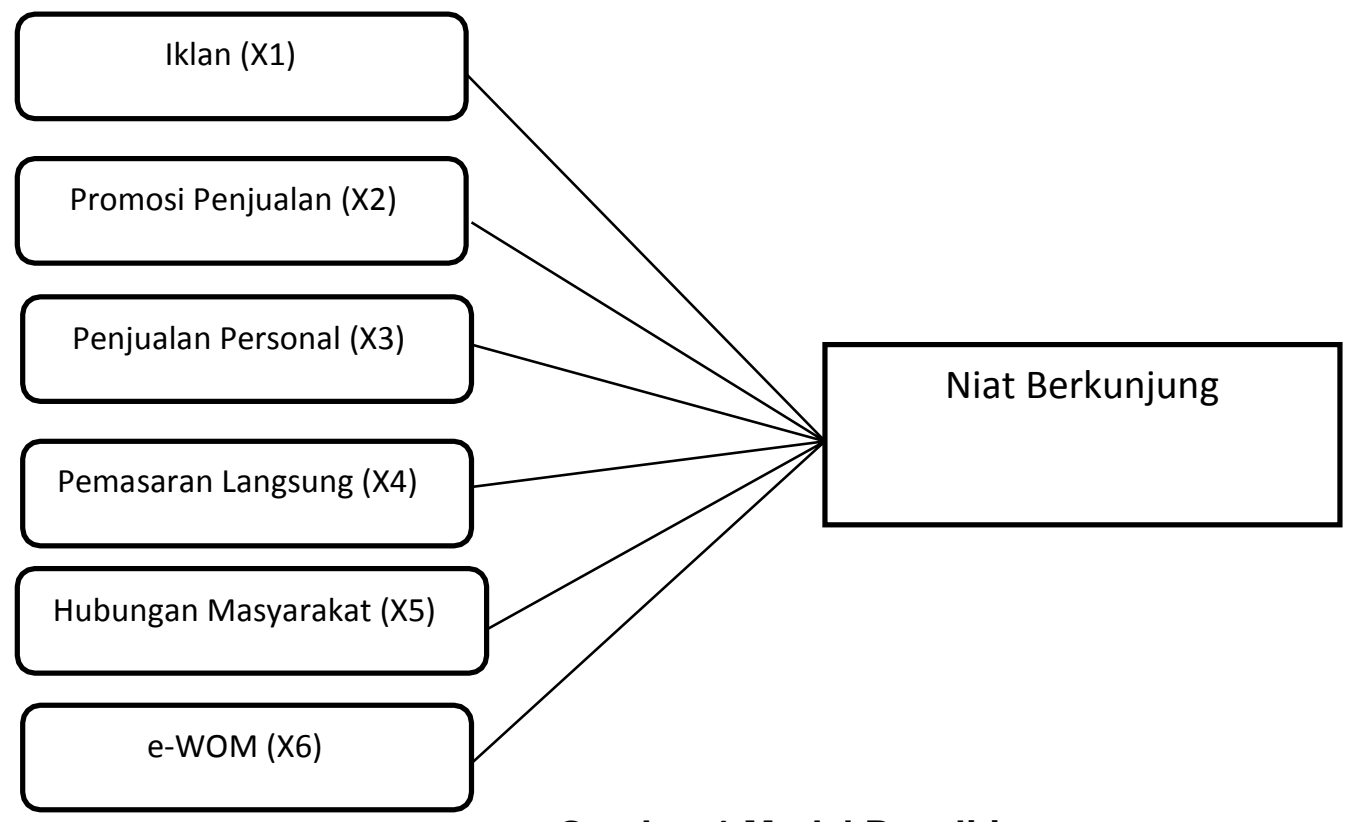

Gambar 1 Model Penelitian

Dari model penelitian diatas maka dibuat hipotesis dibawah ini:

H1: Periklanan berpengaruh signifikan terhadap Niat Berkunjung wisatawan ke Air Terjun Way Lalaan Tanggamus.

H2: Promosi penjualan berpengaruh signifikan terhadap Niat Berkunjung wisatawan ke Air Terjun Way Lalaan Tanggamus.

H3: Penjualan Personal berpengaruh signifikan Niat Berkunjung wisatawan ke Air

Terjun Way Lalaan Tanggamus

H4: Pemasaran Langsung berpengaruh signifikan terhadap Niat Berkunjung wisatawan Air Terjun Way Lalaan Tanggamus

H5: Hubungan Masyarakat berpengaruh signifikan terhadap Niat Berkunjung wisatawan ke Air Terjun Way Lalaan Tanggamus

H6: e-WOM berpengaruh signifikan terhadap Niat Berkunjung wisatawan ke Air Terjun Way Lalaan Tanggamus

\section{METODE PENELITIAN}

Penelitian ini dilaksanakan Air Terjun Way Lalaan sebagai objek wisata yang terletak di Kota Agung, Kabupaten Tanggamus, Provinsi Lampung. Populasi adalah wisatawan yang belum pernah berkunjung ke objek wisata Air Terjun Way Lalaan. Sampel sebanyak 100 orang yang dipilih berdasarkan teknik Puposive sampling. Metode analisis statistik yang digunakan berupa regresi linier berganda, pengujian signifikan simultan uji $(F)$, pengujian signifikan parsial (uji t), dan analisis determinasi (R2). Variable bebas $(X)$ pada penelitian ini adalah advertising, Periklanan (X1), Promosi Penjualan (X2), Penjualan Personal (X3), Pemasaran Langsung (X4), Hubungan Masyarakat (X5) dan e-WOM (X6). Variabel terikat $(\mathrm{Y})$ adalah niat berkunjung. Pengumpulan data dilakukan oleh peneliti Jurnal Pemasaran Kompetitif, Vol. 04, No. 2 / Februari 2021 
dengan menggunakan kuesioner sebagai alat yang paling utama, observasi dan studi kepustakaan.

\section{HASIL}

Analisis Regresi Liniear Berganda menunjukkan bahwa nilai konstanta sebesar 0,502, Periklanan (X1) sebesar 0,440, Promosi Penjualan (X2) sebesar 0,109, Penjualan Personal (X3) sebesar 0,221, Pemasaran Langsung (X4) sebesar 0,233, Hubungan Masyarakat (X5) sebesar 0,171, e-WOM (X6) sebesar 0,255.Dapat dilihat pada tabel 2 dibawah ini:

Tabel 2 Analisis Linear Berganda

\begin{tabular}{|c|c|c|c|c|c|}
\hline \multicolumn{6}{|l|}{ Coefficients $^{\mathrm{a}}$} \\
\hline \multirow[b]{2}{*}{ Model } & \multicolumn{2}{|c|}{$\begin{array}{l}\text { Unstandardized } \\
\text { Coefficients }\end{array}$} & \multirow{2}{*}{\begin{tabular}{|l}
$\begin{array}{l}\text { Standardized } \\
\text { Coefficients }\end{array}$ \\
Beta
\end{tabular}} & \multirow{2}{*}{ t } & \multirow{3}{*}{$\frac{\text { Sig. }}{.002}$} \\
\hline & B & Std. Error & & & \\
\hline \begin{tabular}{|l|l}
1 & (Constant)
\end{tabular} &, 502 & .999 & & 3.143 & \\
\hline $\mathrm{X} 1$ & .314 & .081 & .440 & 3.893 & .000 \\
\hline $\mathrm{X} 2$ & .198 & .095 & .109 & 1.734 & .043 \\
\hline X3 & .280 & .102 & 221 & 2.342 & .032 \\
\hline X4 & .292 & .108 & 233 & 2.140 & .022 \\
\hline $\mathrm{X} 5$ & .211 & .111 & .171 & 2.373 & .025 \\
\hline X6 & .242 & .050 & .255 & 2.425 & .017 \\
\hline
\end{tabular}

Sumber : Output SPSS

\section{Uji Parsial (Uji t)}

Berdasarkan pengujian hipotesis pada variabel Periklanan (X1), Promosi Penjualan (X2), Penjualan Personal (X3), Pemasaran Langsung (X4), Hubungan Masyarakat (X5) dan e-WOM (X6) yang telah dilakukan menyatakan bahwa hipotesis diterima dengan ketentuan $\mathrm{Ha}$ diterima dan $\mathrm{HO}$ ditolak yang berarti variabel $(X)$ berpengaruh secara signifikan terhadap Y Dapat dilihat pada tabel 3 dibawah ini :

Tabel 3 Hasil Hipotesis

\begin{tabular}{|l|l|l|l|l|}
\hline No & Hipotesis t hitung & $t$ table & Hasil \\
\hline 1 & $\begin{array}{l}\text { Terdapat pengaruh periklanan } \\
\text { Terhadap niat berkunjung (H1) }\end{array}$ & 1,69314 & Diterima \\
\hline 2 & $\begin{array}{l}\text { Terdapat pengaruh promosi 1.734 } \\
\text { penjualan } \\
\text { Terhadap niat berkunjung (H2) }\end{array}$ & 1,6614 & Diterima \\
\hline 3 & $\begin{array}{l}\text { Terdapat pengaruh penjualan2.342 } \\
\text { personal } \\
\text { Terhadap niat berkunjung (H3) }\end{array}$ & 1,6614 & Diterima \\
\hline
\end{tabular}


ISSN NO. (PRINT) 2598-0823, (ONLINE) 2598-2893

\begin{tabular}{|l|l|l|l|l|}
\hline 4 & $\begin{array}{l}\text { Terdapat pengaruh pemasaran2.140 } \\
\text { langsung } \\
\text { Terhadap niat berkunjung (H4) }\end{array}$ & 1,6614 & Diterima \\
\hline 5 & $\begin{array}{l}\text { Terdapat pengaruh hubungan2.373 } \\
\text { masyarakat } \\
\text { Terhadap niat berkunjung (H5) }\end{array}$ & 1,6614 & Diterima \\
\hline 6 & $\begin{array}{l}\text { Terdapat pengaruh e-WOM } \\
\text { Terhadap niat berkunjung (H6) }\end{array}$ & 2.425 & 1,6614 & Diterima \\
\hline
\end{tabular}

\section{Sumber : Output SPSS}

\section{Uji Simultan (Uji F)}

Uji simultan atau Uji $F$ menunjukkan hasil $F$ hitung $>F$ tabel $(13,167>2,3)$ pada nilai signifikan 0,000 >0,05. Hal ini menunjukkan bahwa Ho ditolak dan Ha diterima yang menyatakan bahwa secara simultan variabel dari periklanan, promosi penjualan, penjualan personal, pemasaran langsung, hubungan masyarakat dan e-WOM secara bersama- sama memiliki pengaruh yang positif terhadap niat berkunjung. Dapat dilihat pada tabel 4 dibawah ini:

Tabel 4 Hasil Uji F

\begin{tabular}{|c|c|c|c|c|c|c|}
\hline \multicolumn{7}{|c|}{ ANOVA $^{a}$} \\
\hline & & Sum of Squares & Df & Mean Square & $F$ & Sig. \\
\hline \multirow[t]{3}{*}{1} & Regression & 138.176 & 6 & 23.029 & 13.167 & $.000^{b}$ \\
\hline & Residual & 162.664 & 93 & 1.749 & & \\
\hline & Total & 300.840 & 99 & & & \\
\hline \multicolumn{7}{|c|}{ a. Dependent Variable: Y } \\
\hline \multicolumn{7}{|c|}{ b. Predictors: (Constant), X1, X2, X3, X4, X5, X6 } \\
\hline
\end{tabular}

\section{Uji Koefisien Determinasi}

Uji Koefisien Determinasi R2 menunjukkan bahwa pengaruh periklanan (X1), promosi penjualan $(X 2)$, penjualan personal $(X 3)$, pemasaran langsung $(X 4)$, hubungan masyarakat $(X 5)$, dan e-WOM $(X 6)$ terhadap niat berkunjung $(Y)$ sebesar $R 2=0,824$ hal ini berarti variabel periklanan (X1), promosi penjualan (X2), penjualan personal (X3), pemasaran langsung (X4), hubungan masyarakat (X5), dan e-WOM (X6) berpengaruh terhadap niat berkunjung (Y) sebesar $82,4 \%$ sedangkan $17,6 \%$ dipengaruhi oleh variabel atau faktor lain yang tidak diteliti dan tidak termasuk dalam penelitian ini. Dapat dilihat pada tabel 5 dibawah ini:

Tabel 5 Analisis Determinasi R2

\begin{tabular}{|l|l|l|ll|}
\hline \multicolumn{5}{|c|}{ Model Summary } \\
\hline Model & $\mathrm{R}$ & $\mathrm{R}$ Square & $\begin{array}{l}\text { Adjusted } \\
\text { Square }\end{array}$ & $\begin{array}{l}\text { RStd. Error of the } \\
\text { Estimate }\end{array}$ \\
\hline 1 & $.91597^{\mathrm{a}}$ & .839 & .824 & .9123 \\
\hline
\end{tabular}

Predictors: (Constant), X1, X2, X3, X4, X5, X6

Sumber: Output SPS 
Hasil penelitian yang telah peneliti lakukan dengan melihat frekuensi jawaban responden yang menunjukkan bahwa Bauran Komunikasi Pemasaran Terpadu berpengaruh terhadap Niat Berkunjung. Berdasarkan hasil uji analisis yang dilakukan;

1.Variabel yang mempunyai pengaruh terbesar ialah Periklanan (X1) berpengaruh terhadap Niat Berkunjung Wisatawan Air Terjun Way Lalaan, Kabupaten Tanggamus, Lampung. Sehingga hipotesis pada penelitian ini diterima. Periklanan dapat diartikan sebagai setiap bentuk presentasi non personal, promosi ide, barang atau jasa berbayar dengan sponsor tertentu, yang diidentifikasi melalui media cetak (surat kabar dan majalah), disiarkan melalui media radio dan televisi, media jaringan (telepon, kabel, satelit, nirkabel), elektronik media (rekaman suara, rekaman video, video disk, CD- ROM, halaman web), dan media display. Kotler dan Keller (2012). Periklanan yang digunakan disini berbentuk Media cetak seperti Banner yang diletakan dibeberapa lokasi titik keramaian masyarakat (taman kota) di Kota Agung dan Banner yang diletakan disekitaran lokasi Air Terjun Way Lalaan. Penggunaan Media Internet seperti Instagram juga menjadi bentuk kegiatan Periklanan melalui postingan akun Instagram @majestic.tanggamus yang menampilkan pesona dan daya tarik wisata Air Terjun Way Lalaan. Hal ini bertujuan untuk memperkenalkan objek lokasi lebih luas lagi dan dapat menarik Niat Berkunjung Wisatawan.

Hasil tanggapan responden terhadap variabel Periklanan secara keseluruhan menyatakan setuju apabila Periklanan menjadi salah satu aspek penting dalam proses menarik Niat Berkunjung Wisatawan. Hal tersebut sesuai dengan penelitian yang dilakukan oleh Stephany Q.W.Lapian, Silvya M., Sjendry L.(2015) yang melakukan penelitian di Pantai Firdaus dengan Hasil penelitian ini menunjukan bahwa Periklanan berpengaruh terhadap Niat Berkunjung wisatawan ke daerah wisata pantai Firdaus dikarenakan periklanan mampu memberikan identifikasi suatu objek secara jelas kepada konsumen dengan berbagai media seperti cetak maupun elektronik. 2.Variabel Promosi Penjualan (X2) mempunyai kontribusi terkecil dan berpengaruh terhadap Niat Berkunjung Wisatawan Air Terjun Way Lalaan, Kabupaten Tanggamus, Lampung . Sehingga hipotesis ini diterima. Promosi penjualan adalah berbagai intensif jangka pendek untuk mendorong uji coba atau pembelian suatu produk atau layanan termasuk promosi konsumen (seperti kupon dan premi), promosi dagang (seperti tunjangan iklan dan tampilan), dan tenaga penjualan dan bisnis, promosi (kontes untuk perwakilan penjualan). Kotler dan Keller (2012). Bentuk penerapan Promosi Penjualan yang digunakan adalah Kupon Penukaran Produk Teh Kotak untuk setiap tiket masuk ke Air Terjun Way Lalaan. Strategi ini bertujuan untuk menarik wisatawan lebih banyak lagi dengan pemberian insentif dan sebagai alternatif dalam melakukan Integrated Marketing Communication.

Hasil tanggapan responden terhadap variabel Promosi Penjualan secara keseluruhan menyatakan setuju apabila Promosi Penjualan menjadi salah satu aspek penting dalam proses menarik Niat Berkunjung Wisatawan. Hal tersebut sesuai dengan penelitian yang dilakukan oleh Stephany Bima N.H., Edriana P.(2020) yang melakukan penelitian di Tourist Information Center Malioboro Kota Yogyakarta dengan Hasil penelitian ini menunjukan bahwa Promosi Penjualan berpengaruh terhadap Niat Berkunjung wisatawan ke Tourist Information Center Malioboro Kota Yogyakarta. Hal ini dikarenakan Promosi Penjualan mampu menarik Niat Berkunjung wisatawan melalui metode seperti Diskon, Kupon dan Insentif lainnya sehingga dapat memberikan keunikan tersendiri. 


\section{KESIMPULAN}

Berdasarkan dari hasil analisis, pada penelitian ini menunjukkan bahwa semua hipotesis diterima ini berarti bahwa Periklanan (X1), Promosi Penjualan (X2), Penjualan Personal (X3), Pemasaran Langsung (X4), Hubungan Masyarakat (X5) dan e-WOM (X6) berpengaruh terhadap Niat Berkunjung wisatawan di Air Terjun Way Lalaan, Kota Agung, Kabupaten Tanggamus, Provinsi Lampung. Ke enam hipotesis diterima dan signifikan dapat dilihat pada penjelasan dibawah ini:

1. Variabel Periklanan (X1) mempunyai pengaruh yang signifikan terhadap Niat Berkunjung. Periklanan yang dilakukan oleh Air Terjun Way Lalaan telah berjalan dengan maksimal. Periklanan yang dilakukan Air Terjun Way Lalaan tidak hanya melalui banner saja tapi melalu media online yaitu melalui instagram. Saat ini penggunaan media sosial seperti instagram sangat digemari oleh semua orang baik itu kaum muda maupun orang dewasa, orang-orang mencari referensi melalui instagram baik itu referensi wisata, kuliner dan lain-lain.

2. Variabel Promosi Penjualan (X2) berpengaruh signifikan terhadap Niat Berkunjung. Promosi penjualan yang dilakukan oleh Air Terjun Way Lalaan seperti memberikan kupon penukaran tiket masuk berupa produk Teh Kotak kepada wisatawan air terjun Way Lalaan, Kabupaten Tanggamus, Kota Agung Provinsi Lampung sudah baik dan efisien.

3. Variabel Penjualan Personal (X3) berpengaruh secara signifikan terhadap Niat Berkunjung. Tingginya pengaruh Penjualan Personal terhadap Niat Berkunjung adalah kegiatan Event Budaya dan wisata seperti Lampung fair, Festival Teluk Semaka dan Fastival Budaya Wisata Nusantara, Jakarta Convention Center yang diikuti oleh Dinas Pariwisata Tanggamus dan Muli Mekhanai (Duta Wisata) sebagai Promotor.

4. Variabel Pemasaran Langsung (X4) berpengaruh secara signifikan terhadap Niat Berkunjung. Dengan pemasaran langsung Tim Promosi Air Terjun Way Lalaan seperti Dinas Pariwisata dan Muli Mekhani menyebarkan Brosur berupa Catalog yang memuat tentang informasi dan laanan di objek wisata Air Terjun Way Lalaan. Brosur diberikan kepada masyarakat ketika dalam kegiatan atau festival wisata dan budaya yang sedang berkunjung ke stan Dinas Pariwisata Tanggamus. Selain itu juga interakasi dari pemangku wisata yang interaktif dalam memberikan informasi kepada masyarakat dengan penyampaian yang baik dan lugas dalam pemasaran secara langsung dan telah menerapkan metode pemasaran secara professional dan maksimal sehingga masyarakat percaya dengan fasilitas- fasilitas dan keunggulan Air Terjun Way Lalaan.

5. Variabel Hubungan Masyarakat (X5) berpengaruh secara signifikan terhadap Niat Berkunjung. Calon Pengunjung menyatakan bahwa Berita yang tersebar mengenai Air Terjun Way Lalaan sudah baik mulai dari identitas objek wisata hingga keunggulan potensialnya. Hal ini tentu tidak lepas dari kerjasama dengan beberapa media promosi seperti GenPI (Generasi Pesona Indonesia) melalui media sosial, Dinas Komunikasi dan Informasi Kabupaten Tanggamus dan yang paling utama adalah pelayanan informasi yang diberikan oleh Tourism Information Center (TIC) dilokasi.

6. Variabel e-WOM (X6) berpengaruh secara signifikan terhadap Niat Berkunjung. Calon wisatawan sebelum mengunjungi suatu objek wisata lebih sering melihat review online dari wisatawan sebelummnya. Begitupun dengan calon wisatawan Air Terjun Way Lalaan yang menyatakan sering membaca review online tentang objek wisata dari turis lain, hal ini agar mereka dapat memastikan objek wisata yang akan dipilih adalah lokasi 
yang dicari berdasarkan informasi yang tersebar. Pengaruh terbesar pada variabel Periklanan, karena Desain Banner Air Terjun Way Lalaan yang disebar dibeberapa lokasi menarik perhatian masyarakat sehingga terlihat menarik dan Informasi melalui media sosial melalui instagram @majestic.tanggamus disampaikan secara jelas serta mudah untuk ditemukan oleh masyarakat sehingga dapat menarik niat berkunjung calon wisatawan ke Air Terjun Way Lalaan.

\section{DAFTAR PUSTAKA}

Abu bakar, A. M. \& Ilkan, M. 2015. Impact of Online WOM on Destination Trust and Intention to Travel : A Medical Tourism Perspective. Journal of Destination Marketing and Management. Volume 5, Issue 3, Pages 192-201

Achmad Yusuf V. 2018. "Dampak Komunikasi e-WOM Pada Niat Berkunjung Taman Nasional Way Kambas" . Tesis : Program Pascasarjana Magister Manajemen Fakultas Ekonomi Universitas Lampung

Agus Hermawan. 2013. Komunikasi Pemasaran. Penerbit Erlangga.

Ajzen, I. 2005. Attitudes, personality, and behavior. New York : Open University Press

American Marketing Asociation (AMA) yang dikutip oleh Philip Kotler dan Keller Kevin Lane yang diterjemahkan oleh Bob Sabran. 2009.

Bima N.H., Edriana P.2020. "Pengaruh Promosi Penjualan Terhadap Niat Berkunjung Wisatawan Mancanegara ke OWDT (Survei pada Tourist Information Center Malioboro Kota Yogyakarta" Fakultas IImu Administrasi, Univeristas Brawijaya, Malang.

Buchari Alma, , 2004, Manajemen Pemasaran dan Pemasaran Jasa, Edisi Revisi, Bandung: Penerbit CV. Alfabeta.

Fang Chen-Ling \& Lie Ting. 2006. Assessment of Internet Marketing and Competitive Strategies for Leisure Farming Industry in Taiwan. Journal of American Academy of Business. ISSN 15401200, Volume 8 Issue 2, p.296- 300. Cambridge

Fishbein, M. \& Ajzen, I. 1975. Belief, Attitude,Intention and Behavior:An Introduction To Theory And Research. Addison- Wesley.

Ghozali, Imam. 2001. Analisis Multivariate SPSS. Semarang. Badan Penerbit Universitas Dipenegoro

Ghozali, Imam. 2006. Analisis Multivariate SPSS. Semarang. Badan Penerbit Universitas Dipenegoro

Kotler, P. 2012. Prinsip-prinsip Pemasaran. Edisi. 13. Jilid 1. Jakarta: Erlangga

Kotler, Philip and Gary Armstrong. 2012. Pinsip-prinsip Pemasaran. Edisi 13.Jilid Jakarta: Erlangga.

Kotler, Philip and Kevin Lane Keller. 2012. Marketing Management 14th Ed. New Jersey: Pearson Prentice Hall, Inc.

Kotler, Amstrong, Ang, Leong, Tan and Tse. 2011. "Principles of Marketing: An Asian Perspective". Research Collection Lee Kong Chain School of Business.

Jurnal Pemasaran Kompetitif, Vol. 04, No. 2 / Februari 2021 
Stephany Q.W.L., Silvya M., Sjendry L.2015. "Pengaruh Advertising Terhadap Niat Berkunjung Wisatawan Objek Wisata Pantai Firdaus di Kabupaten Minahasa Utara" Fakultas Ekonomi dan Bisnis, Univeristas Sam Ratulangi, Manado.

Lidyawati. 1998. Hubungan antara Intensitas Menonton Iklan di Televisi dan Perilaku Konsumtif. Skripsi (tidak diterbitkan). Surakarta: Fakultas Psikologi UMS.

Oktavia Putri U. 2018. "Peran Bauran Komunikasi Pemasaran Terpadu Terhadap Peningkatan Jumlah Pengunjung Wisatawan Di Pantai Klara (Kelapa Rapet) Bandar Lampung" . Skripsi. Program Studi Manajemen, Fakultas Ekonomi dan Bisnis, Universitas Lampung.

Pitana, I Gede. 2009. Pengantar IImu Pariwisata. ANDI. Yogyakarta.

Pisit Potjanajaruwit. 2014. "Integrated Marketing Communication to Influencing International Standard Energy Economy Car Buying Decision of Consumer in Bangkok". World Acadamy of Science, Engineering and Technology. International Journal of Information and Communication Engineering. Vol:8, No:6 , 2014.

Sanusi A. 2014. Metodologi Penelitian Bisnis. Jakarta Selatan : Salemba Empat

Sudarsono. 1993. Kamus Filsafat dan Psikologi. Jakarta: Rineka Cipta.

Sugiyono. 2009. Pendekatan Kuantitatif, Kualitatif, dan R\&D. Bandung: Alfabeta

Sugiyono. 2013. Pendekatan Kuantitatif, Kualitatif, dan R\&D. Bandung: Alfabeta

Sugiyono. 2015. Pendekatan Kuantitatif, Kualitatif, dan R\&D. Bandung: Alfabeta

Sukmadinata. 2006. Metode Penelitian Kualitatif. Bandung : Graha Aksara

Vivi R, Selmi D dan Rintar Agus S. 2019. "Pengaruh Bauran Pemasaran Terhadap Niat Berkunjung, Studi Kasus :Pantai Pasir Putih Kabupaten Monokwari” . Jurnal Skripsi Penelitian Alumni Fakultas Ekonomi dan Bisnis, Universitas Papua. Vol.1, No.1, Tahun 2019 